\title{
FIRST RECORD OF BACTERIAL GALL OF CHINABERRY CAUSED BY Pseudomonas meliae IN DUHOK, KURDISTAN REGION, IRAQ.
}

\author{
JIVAN M. M. AL-DOSKI ${ }^{*}$ and WAZEER A. HASSAN ${ }^{* *}$ \\ *Dept. of Forestry, College of Agriculture, University of Duhok, Kurdistan Region-Iraq \\ ** Dept. of Plant Protection,College of Agriculture, University of Duhok, Kurdistan Region-Iraq
}

(Received: April 10, 2018; Accepted for Publication: November 12, 2018)

\begin{abstract}
The work done in this research is an attempt to through the light on identification and record on bacterial gall caused by Pseudomonas meliae $\mathbf{L}$. for the first time in Iraq. The infected plants clearly showed soft and woody gall symptoms with deformed shoots and young stems. The field survey in Duhok plantations obviously obtained diseased transplants with percentage range between $25-88 \%$. The pathogenic bacteria revealed the high host specification on chinaberry and Neem plants (Melia indica). The bacterial colonies on Mac Conkey's agar media were white creamy in color, circular in growth, dome shaped shiny, and smooth. Analytical Profile Index API20NE demonstrated that three of eight tests were negatives, Nitrate reduction, Indole production, (Tryptophan) and Urease, whereas capable to hydrolyse arginin but didn't produce levan and non fluorescent. Assimilation tests of ADIpic acid (ADI) and PhenylACetic acid (PAC) were negative, though the bacterial strains were able to utilize glucose (GLU), ARAbinose (ARA), and MANnitol (MAN).
\end{abstract}

KEY WORD: P. meliae, Chainberry, M. Azedarach

\section{INTRODUCTION}

$\mathbf{M}$ elia azedarach L., Meliaceae is a deciduous tree commonly known by several names, white cedar, chinaberry tree, bead-tree, Cape lilac, syringe berry tree, Persian lilac, Indian lilac,

margosa tree, and others (Orwa et al., 2009).

It is a widespread and naturalized in most of the tropics and subtropical countries, which grows as an exotic plant in Iraq, Iran, and Turkey (Neycee et al., 2012).

The tree has beautiful and aromatic flowers and planted as an ornamental plant in gardens and urban landscapes (Mozafarian, 2004). Chinaberry trees are used as fodder, fuel, timber, lipids, poison, and medicine, services as shade or shelter and intercropping.

Bacterial galls formed on the roots and stems of plants became the most important diseases by Pseudomonas meliae on chinaberry and firstly recorded by Ogimi in Japan (Ogimi, 1978).
Pseudomonas meliae Ogimi is a gram negative, non-fluorescent, soil bacterium, and based on DNA/DNA hybridization was placed in the same group with $P$. amygdali, $P$. savastanoi, $P$. ficuserectae and 16 pathovars of $P$. syringae (Gardan et al., 1999).

Based on 16S rRNA gene analysis $P$. meliae has been placed in the $P$. syringae group (genomospecies 2) (Anzai et al., 2000).

In Iran, a chinaberry gall disease was first reported from Shiraz (Ghasemi and Taghavi, 2006). According to Taghavi (2006) and the authors observation, the smilarized symptoms of disease in chinaberry trees are observed with many parenchymatic galls on stems and limbs.

The galls are small but become large and woody as the disease progresses; symptomatic trees confirm dieback of shoots and slow growth on young stems.

The bacterial galls possibly are amorphous, more or less unorganized overgrowths of plant tissues, developing proliferations tissues into more or less 
organized by Pseudomonas and Agrobacterium API 20NE Strip Preparation

galls, as are some Rhodococcus and Agrobacterium galls teratomorphic tissues produced.

The current work aimed to identification the suspected agent of chinaberry galling according to Kock's postulates and biochemical tests. Plantations survey and disease incidence in Duhok province were also documented.

\section{MATERIALS AND METHODS \\ Field Survey and Sampling}

Symptomatic galling shoots and stems of chinaberry trees were collected from several plantations and park in Duhok province [Plantation $=$ Malta (PM), College of Agricultural (PCA)]; [Park = Dlisha (PD), Barzane (PB), Azadi (PA)] $[\underline{\text { Road }}=$ Zerka (RZ), Barzan (RB)] Iraq during leaf fall season in 2016. Disease incidence was measured using an equation:

$\%$ Diseases Incidence $=$

$\frac{\text { Number of Infected Trees }}{\text { Total Number of surveyed trees }} \times 100$

Symptomatic galling shoots and stems were transferred to the laboratory in plastic bags and kept in refrigerator at $-4^{\circ} \mathrm{C}$ for further studies.

\section{Isolation of Bacteria}

The fresh and white galls were washed for 30 min. in running tap water, disinfested for 2 min with $2 \%$ sodium hypochlorite solution and several times rinsed by sterile distilled water. The galls were crushed and soaked in Petri dishes with $2 \mathrm{ml}$ of sterile saline solution $(0.85 \mathrm{NaCl})$ for $30 \mathrm{~min}$. A loopful of the suspension was streaked on nutrient agar (NA), 5\% nutrient agar sugar (NAS), and Mac Conkey's agar (MCA) medium, Suspected typical colonies were picked up after incubated for $72 \mathrm{hrs}$ at $28 \pm 2^{\circ} \mathrm{C}$ under aerobic condition and transfer to slants as purified sub cultures.

\section{Physiological \& Biochemical Tests (API 20NE)}

API 20NE is a homogeneous, simple and fast system, combining of eight conventional and twelve assimilation tests used for identification of bacterial strains and gave a critical verification for the Family Pseudomonadaceae to approve the identification of the genus and species level of the epiphytic strains.
The strip was kept in the incubation box after addition of $5 \mathrm{ml}$ distilled water in to the tray bottom for creation a humid atmosphere.

\section{Inoculum Preparation}

The four colonies grown on 5\% NAS culture medium 18-24hrs old with identical morphology picked up and suspended in $2 \mathrm{ml}$ of normal saline as inoculum preparation.

\section{The Strip Inoculation}

The inoculum was disseminated into the cupules of NO3, TRP, GLU, ADH, UREase, ESC, GEL, and PNPG tests. Subsequently, the cupules of the tests GLU, ADH and URE mineral oil were added until a convex meniscus was formed.

$200 \mu \mathrm{l}$ of the remaining saline suspension was added to the API ampule AUX medium subsequently fill (GLU), (ARA), (MNE), (MAN), (NAG), (MAL), (GNT), (CAP), (ADI), (MLT), (CIT) and (PAC) cupules test to defect a flat or slightly convex. At last, closed the incubation boxes and incubated at 28 $\pm 2^{\circ} \mathrm{C}$ for reading the results after 24 and $48 \mathrm{hrs}$.

\section{Pathogenicity Trial}

According to Taghavi and Ghasemi (2010), Oneyear-old chinaberry, jasmine, olive, neem tree (Melia indica) plants, seedlings of tomato, sunflower, and pepper were achieved from private nursery in KRO; examined for inoculation. Stems of ten plants for each were wounded, and loopful of young bacterial culture $10^{7} \mathrm{CFU}$ on NAS medium was sited in each wound and protected with Para film for four days. The control plants were inoculated by sterile distilled water. The plants kept in a greenhouse at $27{ }^{\circ} \mathrm{C}$ and $76-80 \% \mathrm{RH}$. Symptom development observed for up to 4 months after inoculation.

\section{RESULTS AND DISCUSSION Occurrence and Symptomatology of Bacterial Galls}

Field surveys showed that the pathogen attacks above ground organs of the host in which it was observed the most obvious symptoms were generally teratogen galls on shoot and stem of trees; which initiates small and soft and then becoming large and woody as the disease progresses. Eventually, symptomatic of chinaberry gall trees demonstrated slow growth, dieback, deformation of shoots and young stems (Fig. 1). 


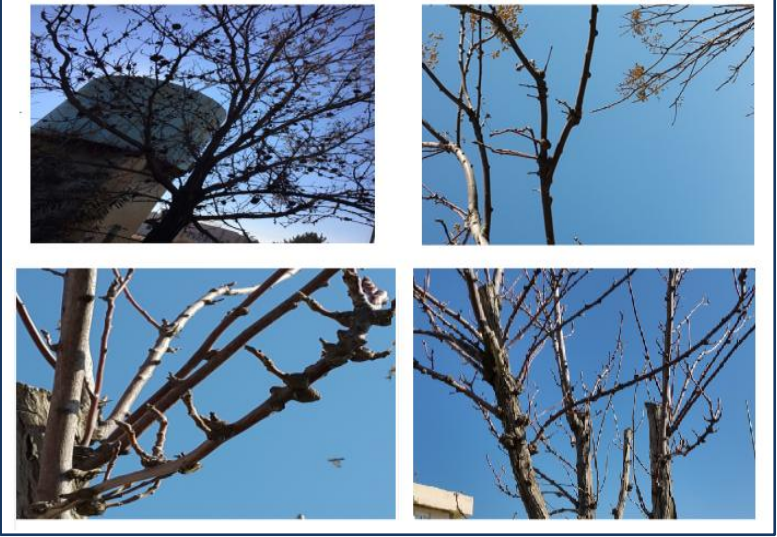

Fig. (1): Symptoms of Bacterial Gall on Chinaberry Stem and Twigs.

Data in (Fig 2) demonstrated that considerable disease incidence on all surveyed plantations, particularly on PD plantation with $88 \%$ infection followed by $66.7 \%$ diseased trees in PCA, the other situation exhibited approximate occurrence of infected plants ranged between $25 \%$ and $37.5 \%$.

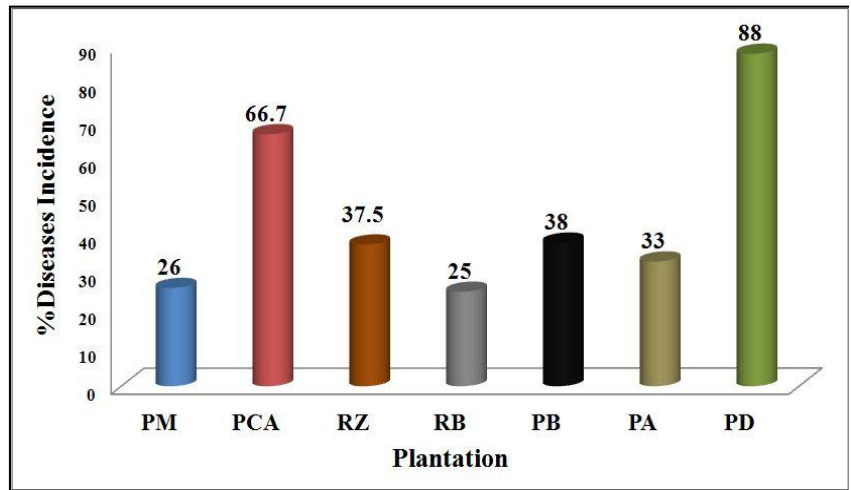

Fig. (2): \% Disease Incidence in several plantations in Duhok province, Iraq during field survey (2016).

\section{Bacterial Identification}

The bacteria isolated from chinaberry galls were all identical in morphological and biochemical characteristics. The colonies of the isolates growth on MCA media were white creamy in color, circular in growth with entire margins, dome shaped, shiny, and smooth(Fig. 3A).

The bacterial strain was gram and oxidase negative for levan production on 5\% NAS, aerobic and non-fluorescent. Bacterial cells were rod shaped and motile through flagellae (Fig.3B).

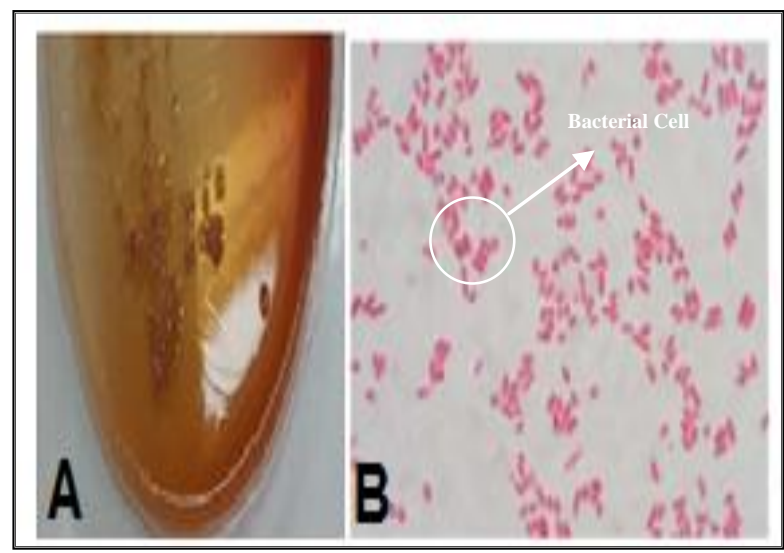

Fig. (3): A: Growth of characteristic, creamy and shiny colonies 2 days old of Pseudomonas meliae,

on Mac Conkey's media; B. P. Meliae shape.

The results of biochemical reaction of bacterial strains $P$. Meliae had similar specific biochemical characters (Fig. 4).

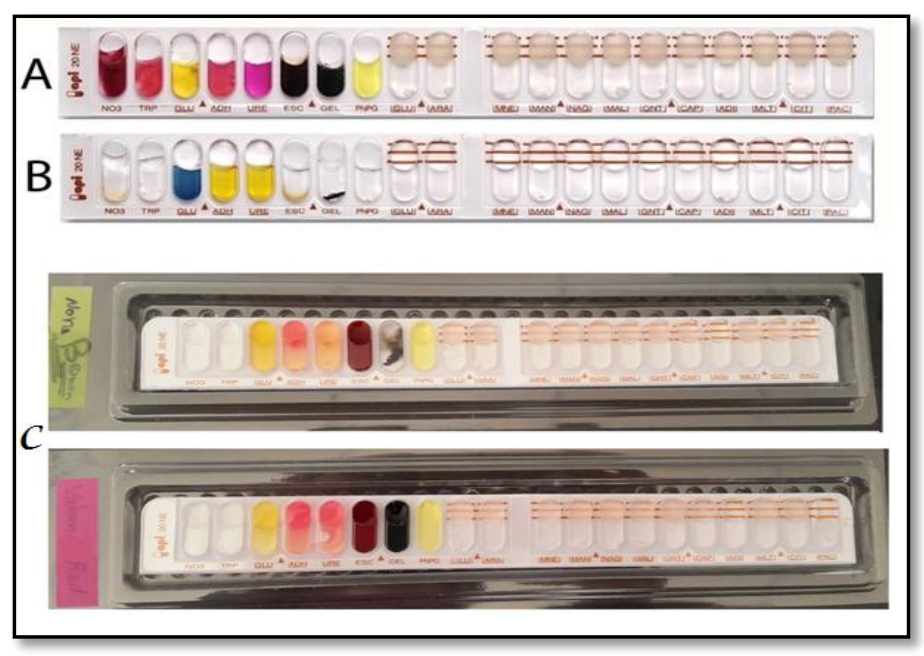

Fig. (4): API 20NE biochemical reaction (A)

Positive test, (B) Negative test and (C) Pseudomonas meliae.

From eight conventional tests of API 20NE it was found only three were negative tests including (NO3), (TRP) and (UREase), whereas these strains were capable for hydrolysis (PNPG), (ADH), (GLU), (ESC) and (GEL) (Table 1).

Assimilation tests of (ADI) and (PAC) were negative, though the bacterial strains were able to utilize (GLU), (ARA), (MNE), (MAN) and (CIT). (GNT), (CAP), (MLT), (NAG) and (MAL) were 
also positive. The isolates were able to hydrolyse arginin but didn't produce levan and fluorescent pigments in contrast to $P$. syringae that did (Jones et al. 1986; Hassan and Al-doski, 2014).
The isolates of $P$. meliae differed from $P$. savastanoi in their production of fluorescent pigment and utilization of mannitol and arabinose (Ogimi, 1978 and Schaad et al., 2001).

Table (1): Biochemical characteristics of Pseudomonas meliae by API 20NE.

\begin{tabular}{|c|c|c|c|c|}
\hline Substrate & \multicolumn{2}{|c|}{ Reactions / Enzymes } & Abbreviation & P. meliae \\
\hline \multirow[t]{2}{*}{ Potassium Nitrate } & \multicolumn{2}{|c|}{ Reduction of Nitrates to Nitrites } & NO3 & Positive \\
\hline & \multicolumn{2}{|c|}{ Reduction of Nitrates to Nitrogen } & & Negative \\
\hline L-tryptophane & \multicolumn{2}{|c|}{ Indole production (tryptophane) } & TRP & Negative \\
\hline D-Glucose & \multicolumn{2}{|c|}{ Fermentation (Glucose) } & GLU & Positive \\
\hline L-Arginine & \multicolumn{2}{|c|}{ Arginine Dihydrolase } & ADH & Positive \\
\hline Urea & \multicolumn{2}{|c|}{ UREase } & UREase & Negative \\
\hline Esculin Ferric Citrate & \multicolumn{2}{|c|}{ Hydrolysis (B-Glucosidase) (Esculin) } & ESC & Positive \\
\hline Gelatin (Bovine Origin) & \multicolumn{2}{|c|}{ Hydrolysis (Protease) (Gelatin) } & GEL & Positive \\
\hline $\begin{array}{l}\text { 4-Nitrophenyl-Pd- } \\
\text { Galactopyranoside }\end{array}$ & \multicolumn{2}{|c|}{$\begin{array}{l}\text { P-Galactosidase(Para-NitroPhenyl-BD- } \\
\text { Galactopyranosidase) }\end{array}$} & PNPG & Positive \\
\hline D-Glucose & & Glucose & GLU & Positive \\
\hline L-Arabinose & & Arabinose & ARA & Positive \\
\hline D-Mannose & & Mannose & MNE & Positive \\
\hline D-Mannitol & & Mannitol & MAN & Positive \\
\hline N-Acetyl-Glucosamine & & N-Acetyl-Glucosamine & NAG & Positive \\
\hline D-Maltose & & Maltose & MAL & Positive \\
\hline Potassium Gluconate & & Potassium Gluconate & GNT & Positive \\
\hline Capric Acid & & Capric Acid & CAP & Positive \\
\hline Adipic Acid & & Adipic Acid & ADI & Negative \\
\hline Malic Acid & & MaLaTe & MLT & Positive \\
\hline Trisodium Citrate & 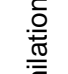 & Trisodium Citrate & CIT & Positive \\
\hline Phenylacetic Acid & $\begin{array}{l}\bar{w} \\
\end{array}$ & Phenylacetic Acid & PAC & Negative \\
\hline
\end{tabular}


The results for pathogenicity test clarified the virulence of $P$. meliae on the inoculated chinaberry and Neem plants in which it was showed typical and diagnostic galls with different size (Fig. 5) .No symptoms were found on the other examined plants. This indicates the high host specification on $M$. azedarach and $M$. indica trees.

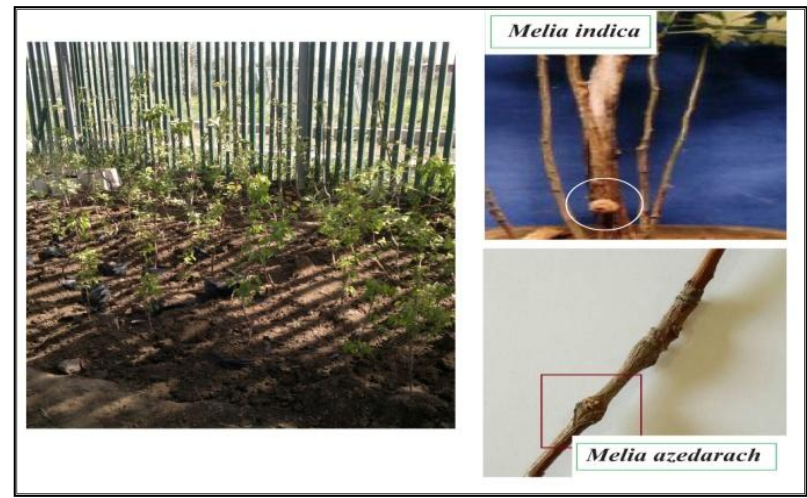

Fig. (5): configuration of gall on stem of Meliae indica and azedarach inoculated with $P$. meliae.

According to the achievement results, we conclude that galls are the most common symptoms of Pseudomonas meliae on chinaberry trees (trunks and limbs), MCA media considered the best culture media for this gram negative bacteria and which avoiding the growth of gram positive bacteria.

The recognition of biochemical features of Pseudomonas meliae using of API 20NE considered crucial test for determination enzymatic activity on various substrates.

Thus, integrated management is required for controlling virulent $P$. meliae in the field, since no complete control can be obtained by any single method. Further research is needed to elucidate the mechanism eliciting about genetic diversity of Pseudomonas meliae.

\section{REFERENCES}

- Anzai, Y.; Kim, H.; Park, J.Y; Wakabayashi, H.; and Oyaizu, H. (2000). Phylogenetic affiliation of the pseudomonads based on 16S rRNA sequence. Int. J. Syst. Evol. Microbiology. 50: 1563-89.
- Gardan, I.; Shafik H.; Belouin S.; Broch R.; Grimont, F.; and Grimont, P.A.D. (1999). DNA relatedness among the pathovars of Pseudomonas syringae and description of Pseudomonas tremae sp. nov. and Pseudomonas cannabina. Int. J. Syst. Bacterial. 49: 469-478.

- Ghasemi, Y.; and Taghavi, M. (2006). The incidence of chinaberry bacterial gall disease in Shiraz. Proc 17th Iran Plant Prot Cong Tehran University, Tehran, Iran, 306p.

- Hassan, W.A; and Jivan M. M. Al-Doski. (2014). Traditional and Molecular Techniques for Isolation and Identification of Bacterial Canker (Pseudomonas syringae pv. syringae) on Stone Fruits M.sc thesis, College of Agriculture, Duhok University.

- Jones, J.B; Gitatis, R.D; and Mc Carter, S.M. (1986). Fluorescence on Single-carbon sources for separation of Pseudomonas syringae pv. syringae, P.syringae pv. tomato and Pseudomonas viridiflava on tomato transplants. Plant Dis. 70:151-153.

- Mozafarian, V. (2004). Introduction of ornamental plants Tehran, Iran. The Islamic Republic of Iran Expert Journal on Landscape Planning and Design Scientific and Educational Quarterly. 62p.

- Neycee, M.A; Nematzadeh, GH.A; Dehestani, A.; and Alavi, M. (2012). Evaluation of antibacterial effects of chinaberry (Melia azedarach) against gram-positive and gram-negative bacteria. International Journal of Agriculture and Crop Sciences. 2227-670.

- Ogimi, C. (1978). Studies on Bacterial gall of Chinaberry (Melia azedarach L.) Caused by Pseudomonas meliae sp. Plant Pathol.57:246.

- Orwa, C.; Jamnadass, R.; Mutua, A.; Anthony, R.S; and Simons, A. (2009). Agroforestree Database: a tree reference and selection guide version 4.0 (http://www.worldagroforestry.org/sites/treedbs/tr eedatabases.asp).

- Schaad, N.W; Jones, J.B; and Chun, W. (2001). Laboratory Guide for Identification of Plant Pathogenic Bacteria. 2nd. Ed. St. Paul, MN, USA. Amer Phytopathol Soc Press, 373p.

- Taghavi, S.M; and Ghasemi, Y. (2010). Etiology of Chinaberry Gall Disease in Iran. Islamic Republic of Iran. Vol. 29 No. 1-2. 


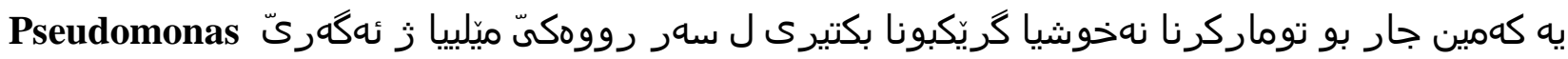
meliae L ل ل دهوكنى -هوريّما كوردستانا عير اقيّ.

يوخته

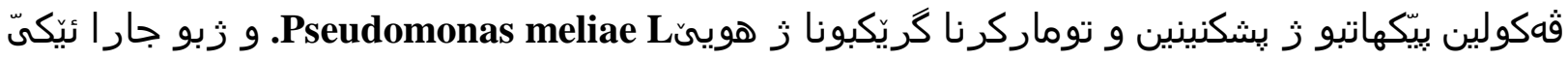

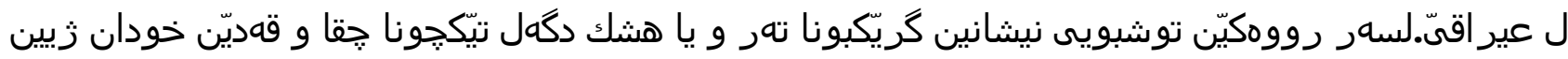

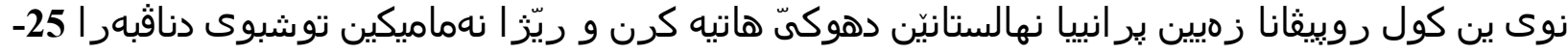

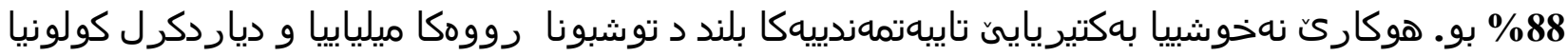

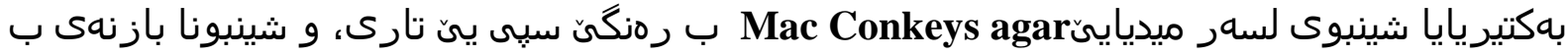

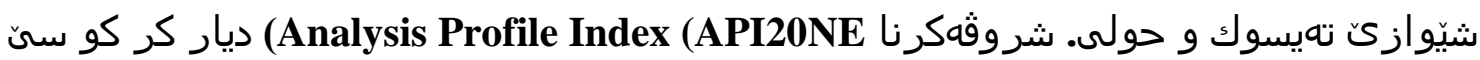

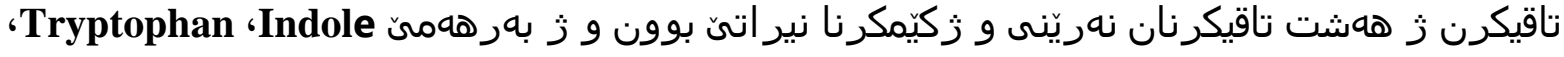

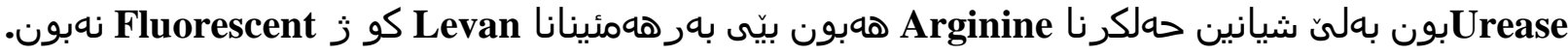

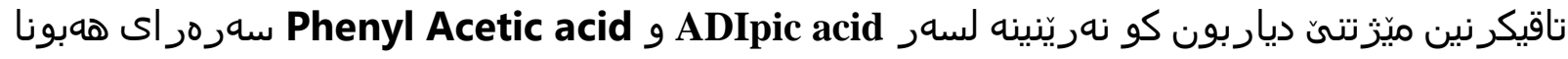

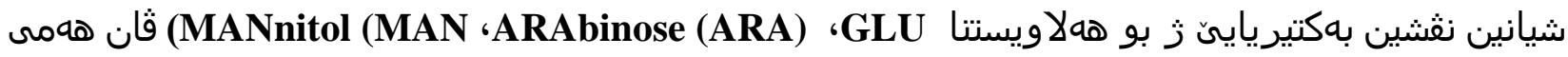
شهكران.

اول تسجيل لمرض التعقد البكتيري لنبات السبحيح المتسبب عن Pseudomonas meliae في دهوك ، إقليم كوردستان ، العراق

الخلاصة

إشتملت الدراسة الكشف وتسجيل تعقد السبحبح المتسبب عن . Pseudomonas meliae L ولأول مرة في

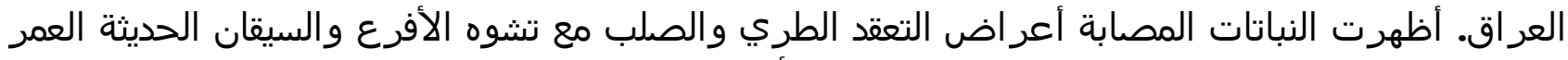

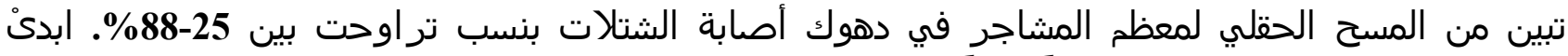

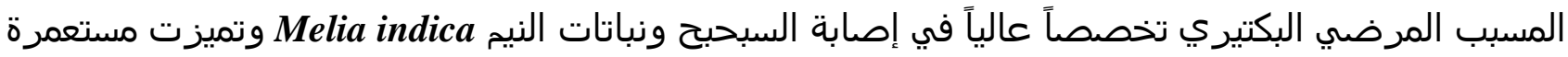

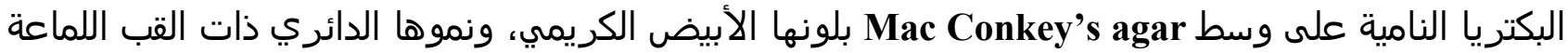

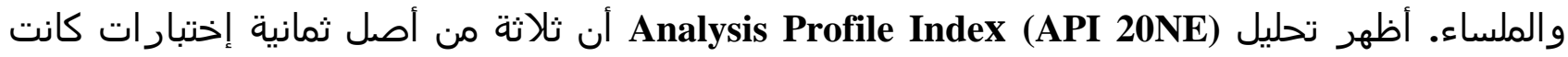

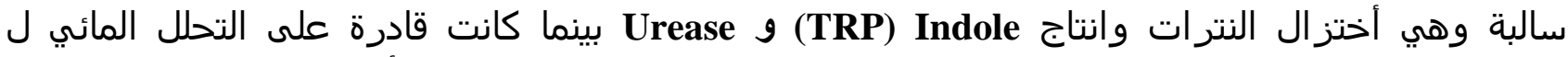
Arginine ، ARAbinose (ARA) ، GLU رغم قدرة سلالات البكتريا على تخليق الكلوكوز Phenyl Acetic acid .MANnitol (MAN) 